\title{
Development of Service Quality Model as Determinants toward Banking Performance
}

\author{
MARCELLIA SUSAN ${ }^{1 *}$, JACINTA WINARTO ${ }^{2}$, IKA GUNAWAN ${ }^{3}$ \\ ${ }^{1}$ MARANATHA CHRISTIAN UNIVERSITY, E-mail: marcellia.susan@gmail.com \\ ${ }^{2,3}$ MARANATHA CHRISTIAN UNIVERSITY
}

\begin{abstract}
Banking services are required by companies to support operation and finance activities. Likewise, the community is also assisted by banks for various financial transactions. Descriptive research was conducted to obtain a depiction of the quality of banking services, specifically private banks. The study also analyzes banking performance and its determinants. Hypothesis testing is conducted to verify the effect of the service quality dimensions on banking performance, and the results show that Reliability, Responsiveness, Assurance, and Tangibles are determinants of Banking Performance. The results of the study can be beneficial for private banks to maintain or improve the service quality to provide better services for the community, which in turn can also improve their performance.
\end{abstract}

Keywords: Service Quality, Performance, Banking

JEL Classification: M31

Recibido: 21 de Febrero de 2021

Aceptado: 25 de Marzo de 2021 


\section{Introduction}

A type of service much needed by the public is banking service which offers banking products that are required related to financial transactions conducted by the public. Law of the Republic of Indonesia number 10 of 1998, about banking, stated that banks are businesses that gathered funds from their clients through deposits and distributed the funds to their clients through credit and or other forms for the improvement of society's quality of life.

The provision of services by banking companies is unique concerning specific service characteristics. In competitive environments, an organization can sustain and succeed by providing good service quality (Aliman \& Mohamad, 2016). Service providers must continue to strive to improve service quality and offer the best service (Kitapci, Akdoganb, \& Dortyo, 2014). Measurement of service quality is commonly a continuous process (Shurair \& Pokharel, 2019). Banking companies do not only need to provide banking services that are deemed to have good quality and can understand customers' assessments of the banking services that they do receive, but also seek to establish customer trust. Companies need to pay attention to their performance, because through achieving good performance, the company may continue to support and develop, thus is expected to provide better services and facilities.

Service quality becomes antecedent and determines other various variables (Pantouvakis, 2014). Several conducted studies obtained the results of a link between service quality and organization performance (Yasin, Correia, \& Lisboa, 2004). Research results related to the effect of service quality on performance do not always give the same results as the literature. Previous research results (Mahmood, Zahari, Yaacob, \& Zin, 2017) did not show any effect of automated service quality dimensions on financial performance.

Relevant to the previously stated phenomenon, research related to Service Quality and Performance of banking companies needs to be conducted. How to establish a banking service quality model that can have an impact on banking performance is the problem of this study. The study aims to analyze the service quality and the performance of the banking service companies. Moreover, the study also intends to test and analyze the effect of service quality on the performance of banking service companies.

\section{Literature Review, Research Model and Hypothesis}

Service quality is the quality perceived by consumers from the services they receive from service providers (Dwivedi, Papazafeiropoulou, Brinkman, \& Lal, 2010). Perceived service quality describes consumer's judgments about product excellence based on perception about what they receive and were given (Zeithaml, 1988). Service providers are required to provide unflinching focus towards their services to make them unique, effective, and efficient (Chang \& Chen, 1998). The dimension of service quality is a determinant factor in measuring perceived service quality (Papaioannou, Assimakopoulos, Sarmaniotis, \& Georgiadis, 2013). Service quality has dimensions that are used by consumers in evaluating services that are consolidated in the five major dimensions of service quality known as SERVQUAL, namely: Tangibles, Reliability, Responsiveness, Assurance, and Empathy (Zeithaml, 1988), and widely used to measure service quality (Yoo \& Park, 2007) (Al-Tamimi \& Jabnoun, 2006).

Performance is basically a measure of achieving a certain level of organizational goals. Performance is a main indicator for a company. Many researchers express various definitions and opinions about performance, but performance measurement standards can vary (Liu \& Wang, 2017). Company performance shows an evaluation of the effectiveness of individuals, groups, or organizations related to financial performance, processes, and human development (Tseng, 2016).

Several other studies with different research objects show the role of service quality for providers of service offerings. Various researches related to service quality has been conducted in the provision of education services (Susan M. , 2011) (Shurair \& Pokharel, 2019), health services (Lien, Wu, Chen, \& Wang, 2014) (Kitapci, Akdoganb, \& Dortyo, 2014) (Susan \& Ratnawati, 2016) (Susan M. , 2018) and 
financial/banking services (Keisidou, Sarigiannidis, Maditinos, \& Thalassinos, 2013) (Liu \& Wang, 2017). In the banking service industry, the quality of services which is offered to customers is the key to success in competitive industry conditions. Several previous studies have shown a link between service quality and company performance. Banking financial institutions can improve the quality of services which is given to customers to increase company profitability (Liu \& Wang, 2017).

Relevant to a company's performance, research conducted by previous researchers on various research objects and the results of the research conducted by (Wijetunge, 2016) also shows that service quality affects company performance. The delivery of the best service quality has a positive impact on company performance, and in the long run, will provide competitive advantages for the company.

The research model is based on theoretical study and empirical research and can be seen in Figure 1.

Figure 1: Research Model

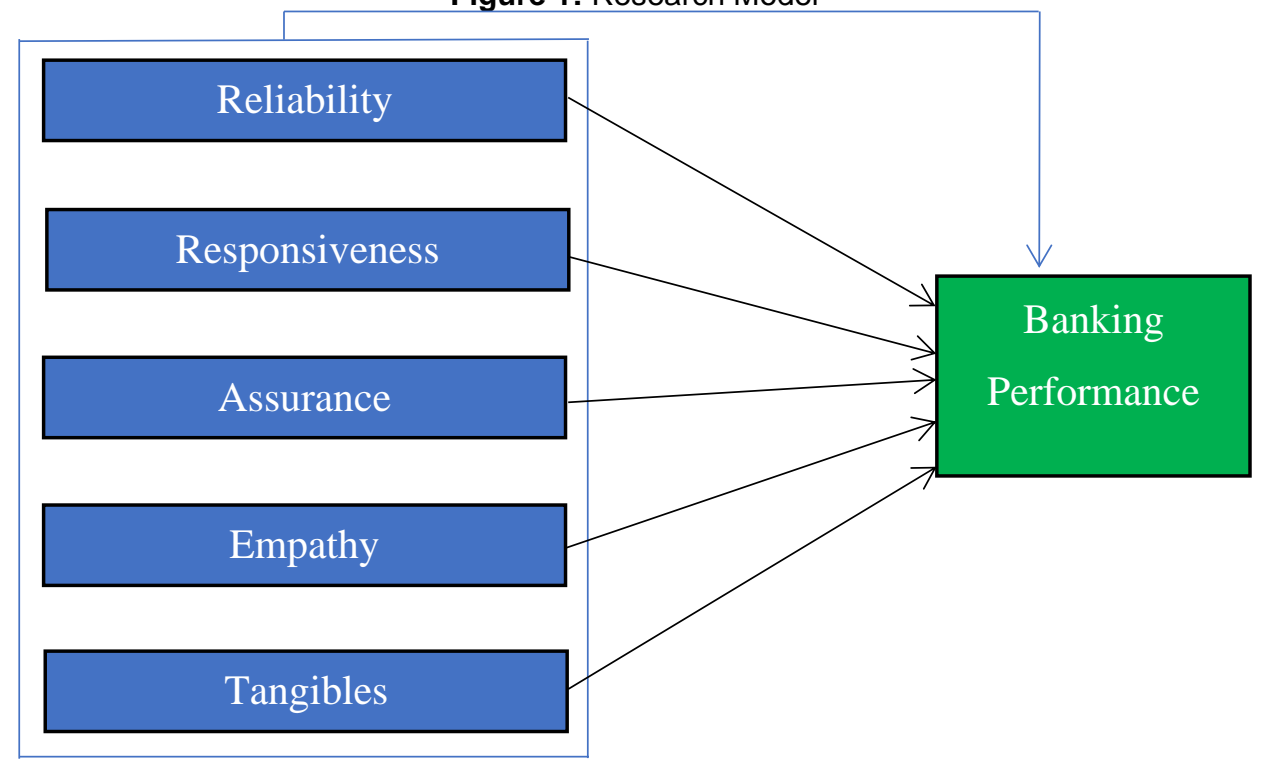

To examine the effect of service quality dimensions on banking performance, the study presents the following hypothesis:

H1: Reliability, Responsiveness, Assurance, Empathy, and Tangibles simultaneously affect Banking Performance

H2: Reliability, Responsiveness, Assurance, Empathy, and Tangibles partially affect Banking Performance

\section{Research Methods}

Descriptive analysis is conducted in this study to determine the value of the independent variables without making comparisons with other variables. Causal analysis is also conducted to test whether one or several variables cause changes in other variables. Reliability, Responsiveness, Assurance, Empathy and Tangibles are independent variables, and Banking Performance is the dependent variable. In this case, the process and people development indicators were used as a measurement scale of banking performance, which is modified from the concept of corporate performance (Tseng, 2016).

The research category is included in the conducted survey research by determining a sample of the population of private bank customers in Bandung, which is one of the major cities in Indonesia, and using a questionnaire as a data collection tool. The respondents were asked to give their evaluation about Reliability, Responsiveness, Assurance, Assurance, Empathy, Tangibles, and Banking Performance indicators, for the past-one-year, using a four-point scale, ranging from " $1=$ strongly 
disagree" to " $4=$ strongly agree". A quantitative approach is used to test the hypothesis. There are a total of 445 complete questionnaires and are used further in data processing, including validity, reliability, classical assumption tests, and multiple regression tests using SPSS 22.

\section{Results}

The research data were obtained by distributing questionnaires to banks' customers by considering the minimum sample size that could represent the population. From a total of 445 data collected, the results showed that the majority of respondents (around 90\%) use the services of BCA (Bank Central Asia) from a total of 17 banks used for their services. In addition, around $56 \%$ of respondents use banking services on average more than 5 times a month, with usage mainly related to savings and ecommerce products.

Data processing is also conducted through the validity and reliability tests via SPSS software which is intended to ensure the accuracy and consistency of the measuring instrument. The results show the validity of a total of 25 indicators of the 6 research variables, using the base Corrected Item-Total Correlation Score that is greater than 0.600 , except for one item with a score of 0.528 . Likewise, the reliability test shows that each research variable is reliable with an Alpha Cronbach's Score of at least 0.800 .

Analysis of service quality provided by banks shows that overall public and private banks have good service quality according to customers' assessment with a total average score of 3.351 out of 4 , while bank performance is also rated well by customers based on a mean score of 3.345 out of 4 . Based on the analysis from each research variable, data processing results show that banks can be relied on by providing services that are appropriate and without errors, and in accordance with the promised time. Besides, banks also express care in solving customer problems. Based on the Reliability variable, the best quality according to customers' assessment is shown in providing the correct service from the beginning of the service (score 3.4629). Based on the Responsiveness aspect, bank employees respond to customer requests quickly, are willing to help customers, and quickly work to overcome mistakes that occur. By these indicators, the lowest score is given by customers in their assessment on the time required to obtain services (score 3.009). The customers also give a positive assessment regarding the Assurance aspect related to bank employees who are polite, trustworthy, and have knowledge in responding to customer questions. In this case, the customers give the lowest score on their assessment of the clarity of information when providing services (3.214). Concerning Empathy aspects, customers assess bank employees to understand their specific needs and have attention to their needs and expectations, with the highest score they give to the accuracy of service advice provided by bank employees (score 3.436). Tangible aspects also received positive ratings from customers as indicated by a score of more than 3 out of 4 from each indicator, both regarding the building and office design, employees' visual, and equipment used by the bank. In this case, the lowest score is given by the customer in their assessment of the visual appeal of the building and office design (score 3.202).

Based on customers' assessment regarding Banking Performance conducted based on Process and People Development aspects, the results of the study indicate a positive customer assessment on bank performance in developing and introducing high-quality new products in accordance with the development of the banking world. Customers also assess that banks have a sophisticated and capable automation system and manage to retain high-quality employees. Customers gave the lowest score on their assessment on the ability of banks to launch new products faster than competitors with a score of 3.175 , while bank performance was rated the best on the ability of banks to develop employee skills with a score of 3.407 .

Data processing is also carried out to answer the research objectives to verify the effect of service quality on banking performance to develop a service quality model as a determinant of banking performance. Data processing using multiple regression analysis is conducted as a subsequent process after having a classical assumption test whose results indicate that the test has been fulfilled. Table 1 shows the correlation of each variable using the Pearson Correlation. The results of the simultaneous 
testing were statistically significant with a p-value of 0.000 (significance level of 0.01 ) as can be seen in Table 2. This shows that Reliability, Responsiveness, Assurance, Empathy, and Tangible aspects simultaneously affect Bank Performance. The results of testing the partial effect of each independent variable on the dependent variables indicate that not all service quality dimensions partially affect bank performance. As seen in Table 3, processing results show that Reliability, Assurance, and Tangible are statistically significant with $p$-values of $0.002,0.000$, and 0.000 respectively (significance level of 0.01), and Responsiveness produces p-values 0.099 (significance level 0.1), while Empathy is statistically insignificant with a $p$-value of 0.170 .

Table 1. Correlation Results

\begin{tabular}{|c|c|c|c|c|c|c|c|}
\hline \multicolumn{2}{|c|}{} & Performance & Reliability & Responsiveness & Assurance & Empathy & Tangible \\
\hline & Performance & 1.000 & .685 & .686 & .746 & .702 & .742 \\
\hline & Reliability & .685 & 1.000 & .783 & .759 & .702 & .585 \\
\cline { 2 - 8 } & Responsiveness & .686 & .783 & 1.000 & .783 & .739 & .603 \\
\hline & Assurance & .746 & .759 & .783 & 1.000 & .815 & .653 \\
\hline Empathy & .702 & .702 & .739 & .815 & 1.000 & .661 \\
\hline & Tangible & .742 & .585 & .603 & .653 & .661 & 1.000 \\
\hline
\end{tabular}

Table 2. F-test Results

\begin{tabular}{|c|c|c|c|c|c|c|}
\hline \multicolumn{2}{|c|}{ Model } & Sum of Squares & df & Mean Square & F & Sig. \\
\hline \multirow{2}{*yyyyyy}{} & Regression & 84.563 & 5 & 16.913 & 194.452 & .000 \\
\cline { 2 - 7 } & Residual & 38.182 & 439 & .087 & & \\
\cline { 2 - 7 } & Total & 122.746 & 444 & & & \\
\hline
\end{tabular}

Table 3. t-test Results

\begin{tabular}{|c|c|c|c|c|c|}
\hline \multirow{2}{*}{ Model } & \multicolumn{2}{|c|}{ Unstandardized Coefficients } & \multirow{2}{*}{\begin{tabular}{|c|} 
Standardized Coefficients \\
Beta
\end{tabular}} & \multirow{2}{*}{$\mathbf{t}$} & \multirow{2}{*}{ Sig. } \\
\hline & B & Std. Error & & & \\
\hline (Constant) & .245 & .102 & & 2.388 & .017 \\
\hline Reliability & .150 & .047 & .147 & 3.159 & .002 \\
\hline Responsiveness & .074 & .045 & .082 & 1.654 & .099 \\
\hline Assurance & .263 & .056 & .257 & 4.729 & .000 \\
\hline Empathy & .065 & .048 & .068 & 1.375 & .170 \\
\hline Tangible & .369 & .035 & .393 & 10.572 & .000 \\
\hline
\end{tabular}

Based on the results of data processing as explained previously, a service quality model as determinants can be formed toward Performance banks, especially private banks. In this case, the Reliability, Responsiveness, Assurance, Empathy, and Tangible variables are the determinants of bank performance with a contribution of $68.5 \%$ based on the Adjusted R Square value. Considering that the dimensions of service quality affect banking performance, banks need to seek to maintain the service quality provided to customers. Banks need to provide reliable services in serving customers, respond and help the customers to solve their problems. Bank employees not only need to be polite and have the bank services knowledge, but they also need to understand the needs and expectations of customers. The banks also need to maintain the physical appearance of the bank. Following the concept regarding factors affecting the organizational performance may come from the internal and external environment of the organization (Mahmood, Zahari, Yaacob, \& Zin, 2017), the results of the study also indicate that there are still various other factors (31.5\%) that can affect bank performance in addition to service quality dimensions. 


\section{Conclusion}

The results of this study provide a depiction of service quality dimensions and banking performance according to the research objectives, which show that private bank customers provide positive assessments on aspects of reliability, responsiveness, assurance, empathy, and tangibles. The customers also provide a positive assessment of banking performance, both regarding the development of processes related to banking activities and the development of bank employees.

Hypothesis testing to verify the relationship between research variables shows that each dimension of service quality has a simultaneous effect on banking performance, but in partially testing the effect of the service quality dimension, it is found that only the reliability, responsiveness, assurance, and tangibles variables affect banking performance. By establishing the banking service quality model, it is expected that customers who are part of the public who need banking services can obtain services that are their right. Due to the limitations of the study that focuses on service quality, further studies may consider other related variables that might determine banking performance, so that banks can get a more overview of the factors that may affect their performance and can seek to improve it.

\section{References}

1. Aliman, N., \& Mohamad, W. (2016). Linking Service Quality, Patients' Satisfaction and Behavioral Intentions: An investigation on Private Healthcare in Malaysia. Procedia - Social and Behavioral Sciences, 224: 141-148.

2. Al-Tamimi, H., \& Jabnoun, N. (2006). Service Quality and Bank Performance: A comparison of the UAE National and Foreign Banks. Finance India, Vol.20 (1): 181-197.

3. Chang, T., \& Chen, S. (1998). Market Orientation, Service Quality and Business Profitability: A Conceptual Model and Empirical Evidence. The Journal of Service Marketing, Vol.12: 246-264.

4. Dwivedi, Y. K., Papazafeiropoulou, A., Brinkman, W., \& Lal, B. (2010). Examining The Influence of Service Quality and Secondary Influence on The Behavioural Intention to Change Internet Service Provider. Inf Syst Front, 12, 207-217.

5. Keisidou, E., Sarigiannidis, L., Maditinos, D., \& Thalassinos, E. (2013). Customer satisfaction, loyalty and financial performance: a holistic approach of the Greek banking sector. International Journal of Bank Marketing, Vol.31 (4), pp.259-288.

6. Kitapci, O., Akdoganb, C., \& Dortyo, I. (2014). The Impact of Service Quality Dimensions on Patient Satisfaction, Repurchase Intentions and Word-of-Mouth Communication in the Public Healthcare Industry. Procedia - Social and Behavioral Sciences, 148: 161-169.

7. Lien, C., Wu, J., Chen, Y., \& Wang, C. (2014). Trust Transfer and The Effect of Service Quality on Trust in The Healthcare Industry. Managing Service Quality, Vol. 24, (4), 399-416.

8. Liu, C., \& Wang, T. (2017). A study on the effect of service quality on customer loyalty and corporate performance in financial industry. Problems and Perspectives in Management, Vol.15 (2-2), 355363.

9. Mahmood, R., Zahari, A., Yaacob, N., \& Zin, S. (2017). Small firm performance: an empiric analysis in Malaysian housing construction industry. international Journal of Housing Markets and Analysis, Vol.10 (1), pp.50-65.

10.Pantouvakis, A. (2014). Market Orientation and Service Quality: Opponents or Colleagues. International Journal of Quality and Service Sciences. International Journal of Quality and Service Sciences, 6(2/3):98-111.

11.Papaioannou, E., Assimakopoulos, C., Sarmaniotis, C., \& Georgiadis, C. K. (2013). Investigating Customer Satisfaction Dimensions With Service Quality of Online Auctions: An Empirical Investigation of E-Bay. Inf Syst E-Bus Manage, 11, 313-330.

12.Shurair, A., \& Pokharel, S. (2019). Stakeholder's perception of service quality: a case in Qatar. Quality Assurance in Education, Vol.27 (4), pp.493-510.

13.Susan, M. (2011). Institution Image, Student Trust and Service Value of Higher Education as Antecedent Variables of Student Loyalty. Media Riset Bisnis \& Manajemen, Vol.11 (1), 38-49. 
14.Susan, M. (2018). Service quality, satisfaction and trust: a study of public hospitals in Bandung, Indonesia. International Journal of Engineering \& Technology, Vol.7 (3.30), pp.393-396.

15.Susan, M., \& Ratnawati, H. (2016). Health Care Service Quality of Public Hospitals in Bandung as Part of Public Services. Review of Integrative Business and Economics Research, Vol. 6, 1, 215-223.

16.Tseng, S. (2016). The effect of knowledge management capability and customer knowledge gaps on corporate performance. Journal of Enterprise Information Management, Vol.29 (1), pp.51-71.

17.Wijetunge, W. (2016). Service quality, competitive advantage and business performance in service providing SMEs in Sri Lanka. International Journal of Scientific and Research Publications, Vol. 6 (7), pp. 720-728.

18.Yasin, M., Correia, E., \& Lisboa, J. (2004). The profitability of customer-targeted quality improvement efforts: an empirical examination. The Magazine, Vol.16 (1), pp.45-49.

19.Yoo, D., \& Park, J. (2007). Perceived service quality: Analyzing relationships among employees, customers, and financial performance. International Journal of Quality \& Reliability Management, Vol.24 (9): 908-926.

20.Zeithaml, V. A. (1988). Consumer Perceptions of Price, Quality, and Value: A Means-End Model and Synthesis of Evidence. Journal of Marketing, Vol. 52, 2-22. 